\title{
Phytoprotection
}

\section{Safe Utilisation of Transgenic Virus-resistant Plants}

\section{Mark Tepfer}

Volume 79, numéro 4, 1998

OECD Workshop - Sustainable Pest Management, Safe Utilization of New Organisms in Biological Control. Montréal, Québec, Canada. September 27-30, 1998.

Atelier de l'OCDE - Gestion durable des ennemis des cultures,

Utilisation sécuritaire de nouveaux organismes de lutte biologique.

Montréal, Québec, Canada. 27-30 Septembre 1998.

URI : https://id.erudit.org/iderudit/706166ar

DOI : https://doi.org/10.7202/706166ar

Aller au sommaire du numéro

Éditeur(s)

Société de protection des plantes du Québec (SPPQ)l

ISSN

0031-9511 (imprimé)

1710-1603 (numérique)

Découvrir la revue

Citer cet article

Tepfer, M. (1998). Safe Utilisation of Transgenic Virus-resistant Plants.

Phytoprotection, 79(4), 107-111. https://doi.org/10.7202/706166ar 


\title{
Safe Utilisation of Transgenic Virus-resistant Plants
}

\author{
Mark Tepfer
}

Laboratoire de Biologie Cellulaire, INRA-Versailles, 78026 Versailles cedex, France

Over the past several decades, one of the important goals of plant breeders has been the introgression of genes conferring resistance to various pathogens into improved crop varieties. However, it is clear that further progress in this area is desireable, since on the order of $40 \%$ of crop production worldwide is lost, pre- and post-harvest, to pests, weeds, and pathogens (Oerke and Dehne, 1997). This genetic approach is clearly preferable to using chemical pesticides, which are more expensive, whose toxicity can cause other problems, and which are generally less compatible with schemes of integrated pest management.

\section{TRANSGENIC VIRUS-RESISTANT PLANTS}

One of the great success stories of transgenic plants, in which they have made a positive contribution to plant breeding, has been the development of artificial virus resistance genes. As has been reviewed elsewhere, the vast majority of transgenic virus-resistant plants express a gene encoding the viral coat protein (CP), although other viral genes have been used as well (for review see Lomonosoff, 1995). Resistance has also been obtained with non-viral genes, including certain animal and yeast genes, but in most cases the quality of resistance obtained has been insufficient for plant breeding purposes (Robaglia and Tepfer, 1996). One of the remarkable features of $\mathrm{CP}$ genes is that they provide protection, often of excellent quality, against the vast majority of plant RNA viruses that have been tested. Another point of interest is the diversity of mechanisms involved in $\mathrm{CP}$-mediated virus resistance. In the earliest case studied in detail, it was shown that expression of the $\mathrm{CP}$ of tobacco mosaic virus (TMV) leads to blockage of the very first stage of virus infection, the uncoating of the virus particles. However, the TMV CP synthesized in transgenic plants also interferes with systemic (leaf-to-leaf) spread of the virus in transgenic plants. This is coherent with current understanding of plant virus movement, since it has been shown that the CP often plays an essential role in systemic spread. More recently, it has been shown that in certain other cases, resistance is not due to the viral protein, but rather to the viral sequences in the RNA transcribed from the transgene. Here, resistance is due to sequence-specific degradation of both the transgene-derived mRNA and the corresponding viral RNA. Although large-scale field use of plants expressing CP genes is too recent to judge, it can be hoped that the ability of a single CP gene to interfere with different steps of the virus infection cycle may contribute to the durability of the protection obtained.

There is a wide consensus that the principle of precaution will be the general guide in proceeding to controlled field release and then in large-scale unrestricted use of transgenic plants. Thus, various potential risks associated with plants expressing viral sequences have been discussed (Palukaitis 1991; Tepfer 1993; Miller et al., 1997; Tepfer et al., 1998). 
GENE FLOW AND TRANSFER OF A RESISTANCE GENE TO RELATED PLANT SPECIES

A question that is pertinent here, although not only to virus resistance genes, is that of potential effects associated with transfer of the transgene from the crop plant to free-living relatives. The risk is that acquisition of virus resistance by the free-living species may increase its fitness, and thus increase its weediness. This is a question for which surprisingly little scientific evidence is available. In the system where this has been best studied, Fuchs and Gonsalves have shown that transfer of a virus resistance transgene from cultivated to wild squash does occur, and that it does confer higher productivity on the virus-resistant wild squash (Fuchs and Gonsalves, 1997). Similar studies are being done concerning transfer of virus-resistance from sugar beet to wild beet (Bartsch et al., 1996; Bartsch, 1997). However, the critical piece of missing information is whether the viruses in question have an impact on the free-living relative under natural conditions. Only if this is the case will transfer of a virus resistance gene have an impact on the fitness or the weediness of the wild species. Unfortunately, very little is known about effects of viruses on the fitness of wild plant species under natural conditions. To my knowledge, there is only a single relevant study (Kelley, 1993).

\section{HETEROLOGOUS ENCAPSIDATION}

When plants are infected by more than one virus of the same group, various forms of heterologous encapsidation are observed: encapsidation of the viral genome of one virus in CP of the other virus, mixed particles composed of the $\mathrm{CP}$ of both viruses, etc. In a similar fashion, heterologous encapsidation is observed in plants expressing a $\mathrm{CP}$ transgene upon infection with a related virus. Since the $\mathrm{CP}$ is the major deter- minant of interaction with vector organisms, heterologous encapsidation can confer on an infecting virus the vector transmission properties associated with the $\mathrm{CP}$ of transgenic origin. For instance, Lecoq et al. (1993) have shown that when a non-aphid-transmissible strain of zucchini yellow mosaic potyvirus infects plants expressing a gene encoding the $\mathrm{CP}$ of a transmissble strain of plum pox potyvirus, it can be transmitted to other plants by aphids. However, heterologous encapsidation is generally considered to have a relatively minor potential impact in most cases, since the virus reverts to encapsidation in the $\mathrm{CP}$ encoded by its own genome as soon as it is transmitted to a non-transgenic host. In addition, since in many cases the site of the CP responsible for interaction with the vector is known, it is possible to eliminate or inactivate this site, and thus eliminate the potential risk factor (see for instance Miller et al. 1997).

\section{RECOMBINATION BETWEEN THE RNA OF AN INFECTING VIRUS AND VIRAL SEQUENCES TRANSCRIBED FROM THE TRANSGENE}

Among the potential ecological risks associated with plants expressing viral sequences, most concern has been expressed with the possible effects of recombination between viral transgene sequences and an infecting virus. See for instance the proceedings of a recent OECD workshop on this subject (Tepfer and Balázs, 1997). In essence, the problem is here again one of potential effects of gene dissemination, but in this case the gene flow of concern is not from plant to plant, but from the host plant to an infecting virus. This is relatively likely to occur, since even from the pre-transgenic world, there is clear evidence of incorporation of plant genomic sequences in certain viral genomes (Mayo and Jolly 1991; Masuta et al., 1992), and also of recombination between viruses (Goulden et al., 1991; Gibbs and Cooper, 1995; Le Gall et al., 1995; Revers et al., 1996). Risks due to 
recombination surely merit evaluation, since it has also been formally demonstrated that indeed recombination between the RNA transcribed from a viral transgene and an infecting virus can occur, both in cauliflower mosaic caulimovirus (Gal et al., 1992; Schoelz and Wintermantel, 1993; Wintemantel and Schoelz, 1996), and in cowpea chlorotic mottle bromovirus (Greene and Allison, 1994; Greene and Allison, 1996).

Over the past several years, we have developed an experimental system for evaluating potential risks associated with recombination, based on cucumoviruses, including several strains of cucumber mosaic virus (CMV), and tomato aspermy virus (TAV). Since risk is generally presented as being composed of two element (risk = hazard $x$ frequency), we are attempting to evaluate both of these elements.

We are using plants expressing a CMV coat protein gene in studies of the frequency of recombination. Here the problem is that the natural baseline is the frequency of recombination in nontransgenic plants infected with two viruses. Since in the latter situation there would be little or no selection pressure in favor of recombinant viruses, in order to determine if the frequency of recombination in transgenic plants is signficantly above baseline, this must also be evaluated under conditions of minimal selection pressure on the virus population. We have developed sensitive molecular techniques to detect rare recombinant molecules in the presence of a large excess on non-recombinants (Aaziz et al., in press), and are currently using the strategy developed to carry out the first evaluations of the frequency of recombination in transgenic plants, as well as in non-transgenic ones infected by both CMV and TAV.

In a first approach to evaluation of the potential hazard associated with recombinant cucumoviruses, in collaboration with other laboratories, we have created artificial recombinants either between CMV strains, or between CMV and TAV, and have then evaluated the biological properties of the recombinant strains (Salánki et al., 1997; Jacquemond et al., 1997). These results, and those of other groups, have shown that certain artificial CMV/TAV recombinants can induce symptoms worse than those caused by the parental strains (Ding et al., 1996; Salánki et al., 1997). In another study, a different CMV/TAV recombinant was shown to have a selective advantage over the parental viruses when plants were co-inoculated with the two viruses (Fernandez-Cuartero, 1994).

\section{CONCLUSIONS}

For two of the potential risks discussed here, the underlying mechanism is one of gene flow, either from plant to plant, or from plant to virus. In both cases, it is reasonable to consider that gene flow will indeed occur. Where sexually compatible cultivated and wild species grow in proximity (the case for sugar beet and rapeseed in Europe and North America, with in addition squash and sunflower in North America) one should expect transfer of the transgene to populations of the wild species. The essential question this raises, is what are the consequences? Will the transgene modify the fitness of the wild species? It is pertinent to also consider what is the proper baseline for evaluating this potential risk. For instance, has introduction of natural resistance genes into cultivated plants led to their transmission to wild relatives?

Since even with a limited number of plants, transfer of viral sequences from transgene-derived mRNA to an infecting viral genome has been observed under experimental conditions, it is reasonable to expect that this will also occur in the field. Here again, the essential question is one of potential consequences. Could they be in any way different from recombinants that arise naturally in plants infected simultaneously with more than one virus? In particular, could such recombinant viruses be more aggressive than currently known strains? In any case, one would expect that the prevalence of newly-created recombinant viruses will be extremely low, unless they have a selective advantage relative to other strains. Here too, an essential element 
to evaluation is the question of baseline. Since recombination between viruses is a key component to generating the variability that allows virus evolution (Roossinck, 1997), is there any reason to expect either qualitative or quantitative differences between recombinants created by recombination between viruses, compared to those that would arise by recombination between transgene sequences and an infecting virus?

\section{QUESTIONS FOR DISCUSSION}

1) Will horizontal transfer of virus resistance genes to wild plant species increase their weediness?

2) When and how should we start including transgenic plants in integrated pest management strategies?

3) Beyond the strictly scientific aspects of risk assessment, how to integrate potential risk in an overall risk-benefit analysis?

\section{REFERENCES}

Aaziz R, Salánki K, Balázs E, Jacquemond M, Tepfer M. (in press) Strategies for detection of recombination in virus-infected plants expressing a viral transgene. in J. Schiemann, R. Casper (eds.) Proc. 5th Int. Symp. Biosafety results of field tests of genetically modified plants and microorganisms.

Bartsch D (1997) Ecological impact of transgenic virus-resistance in crop, weed, and wild plant populations (due to potential alterations of plant invasiveness). In $\mathrm{M}$ Tepfer, E Balázs (Eds) Virus-resistant transgenic plants: potential ecological impact. INRA and Springer-Verlag, Versailles and Heidelberg, pp 107-113.

Bartsch D, Schmidt M, Pohl-Orf M, Haag C, Schuphan I (1996) Competitiveness of transgenic sugar beet resistant to beet necrotic yellow vein virus and potential impact on wild beet populations. Mol. Ecol. 5: 199-205.

Ding S-W, Shi B-J, Li W-X, Symons RH (1996) An interspecies hybrid RNA virus is significantly more virulent than either parental virus. Proc. Natl. Acad. Sci. USA 93: $7470-7474$.
Fernandez-Cuartero $B$, Burgyán J, Aranda MA, Salánki K, Moriones E, García-Arenal $F$ (1994) Increase in the relative fitness of a plant virus RNA associated with its recombinant nature. Virology 203: 373377.

Fuchs M, Gonsalves D (1997) Risk assessment of gene flow associated with release of virus-resistant transgenic crop plants. In M Tepfer, E Balázs (Eds) Virusresistant transgenic plants: potential ecological impact. INRA and SpringerVerlag, Versailles and Heidelberg, pp 114120.

Gal S, Pisan B, Hohn T, Grimsley N, Hohn B (1992) Agroinfection of transgenic plants leads to viable cauliflower mosaic virus by intermolecular recombination. Virology 187: 525-533.

Gibbs MJ, Cooper JI (1995) A recombinational event in the history of luteoviruses probably induced by base-pairing between the genomes of two distinct viruses. Virology 206: 1129-1132.

Goulden MG, Lomonossoff GP, Wood KR, Davies JW (1991) A model for the generation of tobacco rattle virus (TRV) isolates: pea early browning virus RNA2 acquires TRV sequences from both RNA1 and RNA2. J. Gen. Virol. 72: 1751-1754.

Greene AE, Allison RF (1994) Recombination between viral RNA and transgenic plant transcripts. Science 263: 1423-1425.

Greene AE, Allison RF (1996) Deletions in the $3^{\prime}$ untranslated region of cowpea chlorotic mottle virus transgene reduce recovery of recombinant viruses in transgenic plants. Virology 225: 231-234.

Jacquemond M, Salánki K, Carrère I, Balázs E, Tepfer M (1997) Behavior of cucumovirus pseudorecombinant and recombinant strains in solanaceous hosts. In M Tepfer, E Balázs (Eds) Virus-resistant transgenic plants: potential ecological impact. INRA and Springer-Verlag, Versailles and Heidelberg, pp 52-65.

Kelley SE (1993) Virus and the advantage of sex in Anthoxanthum odoratum: a review. Plant Species Biol. 8: 217-223.

Lecoq H, Ravelonandro M, Wipf-Scheibel C, Monsion M, Raccah B, Dunez J (1993) Aphid transmission of a non-aphid-transmissible strain of zucchini yellow mosaic potyvirus from transgenic plants expressing the capsid protein of plum pox potyvirus. Mol. Plant-Microbe Interact. 6: 403-406.

Le Gall O, Lanneau M, Candresse T, Dunez $J$ (1995) The nucleotide sequence of the RNA2 of the English serotype of tomato black ring virus: RNA recombination in the history of nepoviruses. J. Gen. Virol. 76: 1279-1283. 
Lomonossoff GP (1995) Pathogen-derived resistance to plant viruses. Ann. Rev. Phytopathol. 33, 323-343.

Masuta C, Kuwata S, Matsuzaki T, Takanami Y, Koiwai A (1992) A plant virus satellite RNA exhibits significant sequence complementarity to a chloroplast tRNA. Nucl. Acids Res. 20: 2885.

Mayo MA, Jolly CA (1991) The 5'-terminal sequence of potato leafroll virus RNA: evidence of recombination between virus and host. J. Gen. Virol. 72: 2591-2595.

Miller WA, Koev G, Mohan BR (1997) Are there risks associated with transgenic resistance to luteoviruses? Plant Dis. 81: 700-710.

Oerke EC, Dehne HW (1997) Global crop production and the efficacy of crop protection - current situation and futur trends. Eur. J. Plant Pathol. 103, 203-215.

Palukaitis $P$ (1991) Virus-mediated genetic transfer in plants. In: Levin M, Strauss $\mathrm{H}$, eds. Risk assessment in genetic engineering. McGraw-Hill, New York, pp 140-162.

Revers F, Le Gall O, Candresse T, Le Romancer M, Dunez J (1996) Frequent occurrence of recombinant potyvirus isolates. J. Gen. Virol. 77: 1953-1965.

Robaglia C, Tepfer M (1996) Using non-viral genes to engineer virus resistance in plants. Biotech. Ann. Rev. 2: 185-204.
Roossinck, M (1997) Mechanisms of plant virus evolution. Ann. Rev. Phytopath. 35: 191-209.

Salánki K, Carrère I, Jacquemond M, Balázs E, Tepfer M (1997) Biological properties of pseudorecombinant and recombinant strains created with cucumber mosaic virus and tomato aspermy virus. J. Virol. 71: 3597-3602.

Schoelz JE, Wintermantel WM (1993) Expansion of viral host range through complementation and recombination in transgenic plants. Plant Cell 5: 1669-1679.

Tepfer M (1993) Viral genes and transgenic plants. Bio/Technology 11: 1125-1132.

Tepfer M, Balázs E (1997) (eds.) “Virus-resistant transgenic plants: potential ecological impact". INRA and Springer-Verlag, Versailles and Heidelberg $126 \mathrm{p}$.

Tepfer M, Lecoq H, Jacquemond M (1998) Evaluation des risques écologiques potentiels associés à l'utilisation agronomique de plantes exprimant des gènes viraux. Virologie 2, 17-31.

Wintermantel WM, Schoelz JE (1996) Isolation of recombinant viruses between cauliflower mosaic virus and a viral gene in transgenic plants under conditions of moderate selection pressure. Virology 223: 156-164. 